\title{
Phoretic uropodine mites (Acari: Mesostigmata) associated with the red palm weevil, Rhynchophorus ferrugineus (Coleoptera: Curculionidae) in Iran
}

\author{
V.R. Farmahiny Farahani, ${ }^{1}$ A. Ahadiyat, ${ }^{1}$ P. Mašán, ${ }^{2}$ M.A. Dehvari ${ }^{1}$ \\ ${ }^{1}$ Department of Entomology, Science and Research Branch, Islamic Azad University, Tehran, Iran; \\ ${ }^{2}$ Institute of Zoology, Slovak Academy of Sciences, Bratislava, Slovakia
}

\begin{abstract}
During an investigation on phoretic mite associates of the red palm weevil, Rhynchophorus ferrugineus, in Sistan and Balouchestan Province of Iran, two uropodine species were collected and identified as Centrouropoda almerodai (Uropodidae) and Uroobovella marginata (Dinychidae). This is the first record of the genus Centrouropoda from Iran and the first record of phoretic mites associated with this weevil from the country.
\end{abstract}

\section{Introduction}

The red palm weevil, Rhynchophorus ferrugineus (Olivier, 1790), is considered as an important pest of palm trees in some Asian and European countries (Murphy \& Briscoe, 1999; Faleiro, 2006; Longo \& Ragusa, 2006). It is an internal quarantine pest in Saravan region of Sistan and Balouchestan Province, Iran (Avand-Faghih, 2007). Many organisms, including viruses, bacteria, fungi, nematodes, mites, insects and vertebrates, have been found in association with the red

Correspondence: Ali Ahadiyat, Department of Entomology, Science and Research Branch, Islamic Azad University, Hesarak, Poonak, Tehran, Iran. Tel.: +98.912.6126821 - Fax: +98.21.43851839.

E-mails: ali.ahadiyat@hotmail.com ; a.ahadiyat@srbiau.ac.ir

Key words: Faunistic; Uropodina; phoresy; taxonomy.

Acknowledgements: the authors would like to thank Sahebeh Ghasemi Moghadam, Yahya Ostadi, Mahdi Khodaveisi and Mohammad Asgari for their kind help during this research.

Received for publication: 27 February 2016.

Revision received: 7 May 2016.

Accepted for publication: 8 May 2016.

(C) Copyright V.R. Farmahiny Farahani et al., 2016

Licensee PAGEPress, Italy

Journal of Entomological and Acarological Research 2016; $48: 5853$

doi:10.4081/jear.2016.5853

This article is distributed under the terms of the Creative Commons Attribution Noncommercial License (by-nc 4.0) which permits any noncommercial use, distribution, and reproduction in any medium, provided the original author(s) and source are credited. palm weevil (Mazza et al., 2014). Among them, mites are considered as one of the most inadequately studied group (Dilipkumar et al., 2015), with 26 identified species of different taxa (Kontschán et al., 2014; Dilipkumar et al., 2015). So far, 11 known and four unidentified species of the cohort Uropodina have been found to be related to this beetle from different Asian and European countries (Kontschán et al., 2014; Dilipkumar et al., 2015).

Nearly two years ago, eight adult beetles of the red palm weevil carrying phoretically attached uropodine mites were collected in Sistan and Balouchestan Province of Iran. The aim of this paper is to introduce uropodine mite associates of this weevil in Iran, comment them and contribute to the present knowledge of phoretic associates of the beetle in Eurasia.

\section{Materials and methods}

Adult beetles of the red palm weevil (a total of 80 individuals) were collected by pheromone traps situated in an orchard of date palm (Phoenix dactylifera Linnaeus, 1753) during March-April 2014 with 515 day intervals for sampling. Mite specimens were taken from some parts of the bodies, deposited into vial containing $75 \%$ of ethanol, cleared by Nesbitt's fluid and mounted in Hoyer's medium (Walter \& Krantz, 2009). All measurements are given in micrometers $(\mu \mathrm{m})$. All the specimens are deposited at the Acarological Collection of the Department of Entomology, College of Agriculture and Natural Resources, Science and Research Branch, Islamic Azad University, Tehran, Iran.

\section{Results}

Among 80 adult weevils collected using pheromone traps, eight specimens were bringing deutonymphs of phoretic mites under elytra, snout or on femur (Table 1). Two species belonging to the cohort Uropodina, Centrouropoda almerodai and Uroobovella marginata, and one unidentified astigmatine species were observed (Table 1).

\section{Centrouropoda almerodai Hiramatsu \& Hirschmann (Uropodidae)}

(Figures 1, 3A, 4A, 5A, 6A and 7)

Centrouropoda almerodai Hiramatsu \& Hirschmann, 1992 in Wiśniewski et al., 1992: 313.

Material examined. Four deutonymphs, Mehrestan City, Sistan and Baluchestan Province, latitude: N $27^{\circ} 08^{\prime}$, longitude: E $61^{\circ} 40^{\prime}$, alti- 
tude: 1180 m a.s.l., on Rhynchophorus ferrugineus, 29 March 2014; 12 deutonymphs, from the same location and beetle species, 8 and 14 April 2014. All collected by Mohammad Azim Dehvari.

Notes. Deutonymphs of this species were adhered by anal pedicels to the under surfaces of elytra of adult weevils, as the only location for adhering, in high abundance. Anal pedicels were very short, broad and dark brown in color (Figure 3A). The average number of deutonymphs of this species under elytra per infested beetle individual was 44.63 (Table 1). The maximum number of this mite on one beetle was 89 .

\section{Uroobovella marginata (C. L. Koch) (Dinychidae)}

(Figures 2, 3B, 4B, 5B, 6B, 8 and 9)

Notaspis marginatus C. L. Koch, 1839: 27.

Fuscuropoda marginatus - Schweizer, 1961: 195.

Uroobovella marginata - Hirschmann \& Zirngiebl-Nicol, 1962: 59, 75; Karg, 1989: 134-142, 150; Mašán, 2001: 220-222.

Material examined. Ten deutonymphs, Mehrestan City, Sistan and Baluchestan Province, latitude: N $27^{\circ} 08^{\prime}$, longitude: E $61^{\circ} 40^{\prime}$, altitude: 1180 m a.s.l., on Rhynchophorus ferrugineus, 29 March 2014; 14 deutonymphs, from the same location and beetle species, 8 and 14 April 2014. All collected by Mohammad Azim Dehvari.
Notes. Deutonymphs of this species were adhered by anal pedicels to the weevils' legs and snouts in almost middle abundance. Anal pedicels were medium to long in size, slender and pale brown in color (Figures $3 \mathrm{~B}$ and 9 ). The average number of deutonymphs of this species on the body per adult beetle was 16.75 (Table 1). The maximum numbers of this species under snout and on femur of one beetle were 34 and 11, respectively.

\section{Discussion}

Centrouropoda almerodai is firstly recorded in Iran and also the genus Centrouropoda Berlese, 1916 has not been recorded previously in this country. In association with $R$. ferrugineus, the species has been previously recorded from Egypt, Italy, Malaysia, Malta, the Philippines and UAE (Dilipkumar et al., 2015). Porcelli et al. (2009) found phoretic deutonymphs of $C$. almerodai on some parts of adult red palm weevils, including underside of the elytra, rarely on wings and first abdominal tergum. Ragusa et al. (2009) collected the mites on membranous wings and under elytra. Mazza et al. (2011) found it settling preferentially under the elytra. We found it in high abundance under elytra (273 individuals) of the weevil bodies (Table 1).

Table 1. Numbers of mite deutonymphs associated with Rhynchophorus ferrugineus (eight adult specimens)

\begin{tabular}{|c|c|c|c|c|c|c|}
\hline Mite species & $\begin{array}{l}\text { Location } \\
\text { on beetle }\end{array}$ & $\begin{array}{l}\text { Number of } \\
\text { phoretic mites } \\
\text { on beetle }\end{array}$ & $\begin{array}{l}\text { Number of } \\
\text { mites in alcohol } \\
\text { sediments }\end{array}$ & $\begin{array}{c}\text { Total number } \\
\text { of mites }\end{array}$ & $\begin{array}{l}\text { Percent of } \\
\text { total mites } \\
\text { found }\end{array}$ & $\begin{array}{c}\text { Average number } \\
\text { of mites per } \\
\text { beetle individual }\end{array}$ \\
\hline Centrouropoda almerodai & Under elytra & 273 & 84 & 357 & 72.71 & 44.63 \\
\hline Uroobovella marginata & $\begin{array}{l}\text { Under snout } \\
\text { On femur }\end{array}$ & $\begin{array}{l}74 \\
28\end{array}$ & 32 & 134 & 27.29 & 16.75 \\
\hline Total & - & 375 & 116 & 491 & 100 & 61.38 \\
\hline Unidentified Astigmatina & Under elytra & 19 & Numerous & - & - & - \\
\hline
\end{tabular}

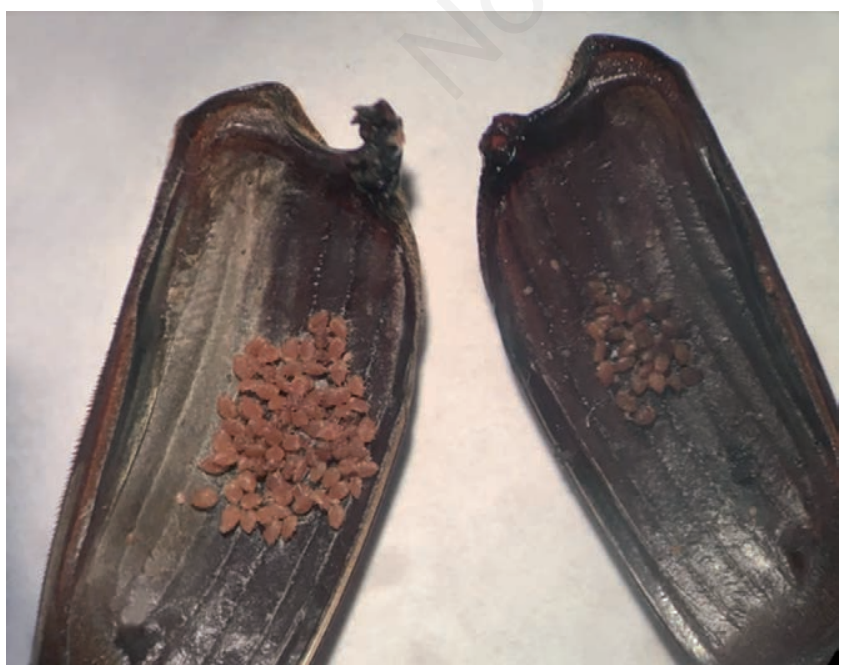

Figure 1. Deutonymphs of Centrouropoda almerodai under elytra of Rhychophorus ferrugineus.

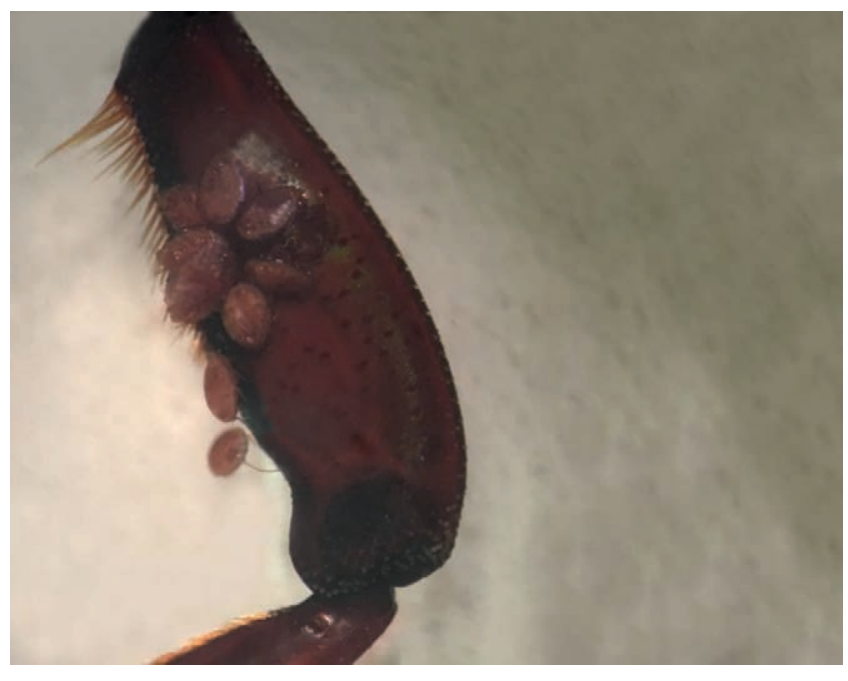

Figure 2. Deutonymphs of Uroobovella marginata on femur of Rhynchophorus ferrugineus. 


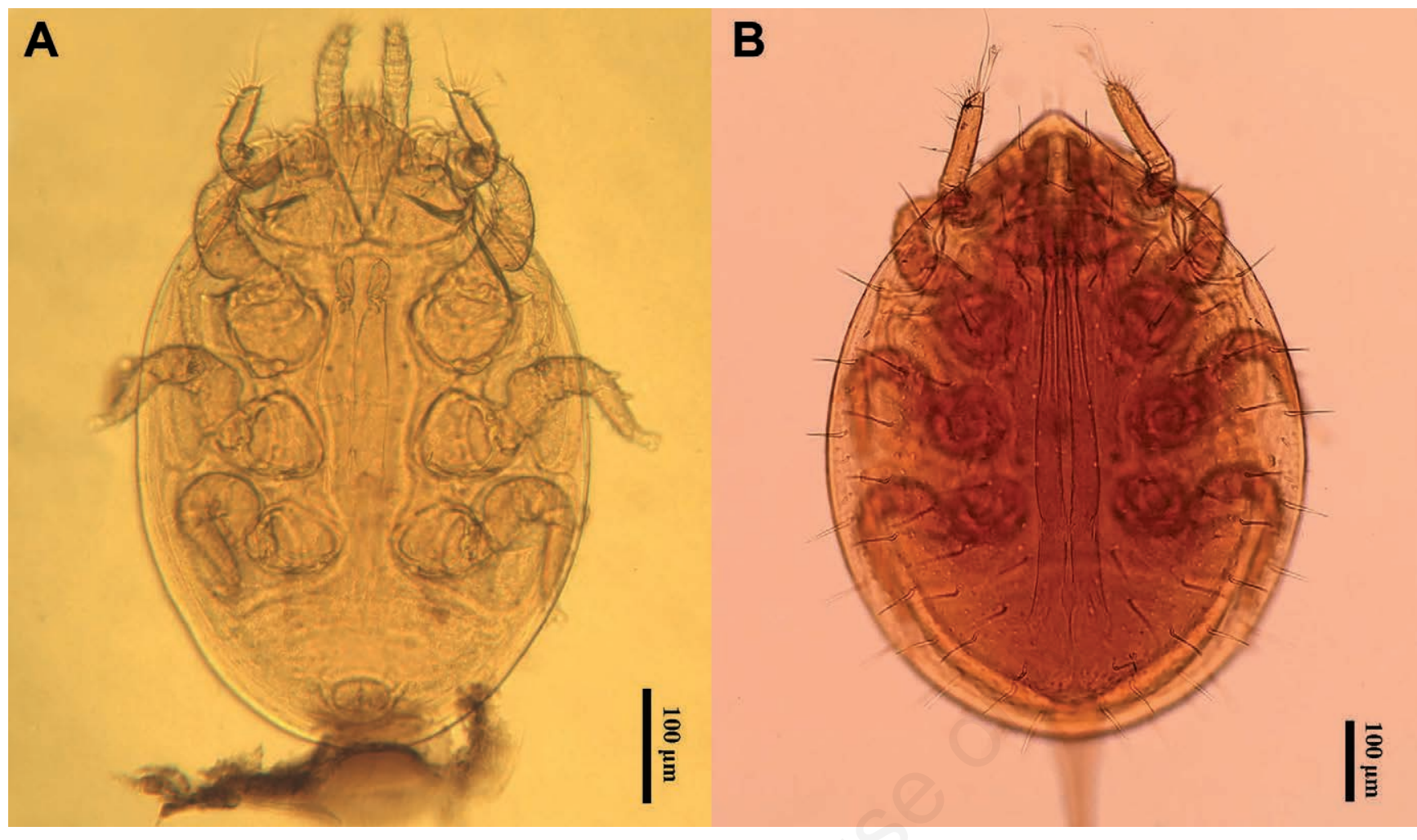

Figure 3. Idiosomal aspect of Centrouropoda almerodai (A) and dorsal idiosoma of Uroobovella marginata (B).

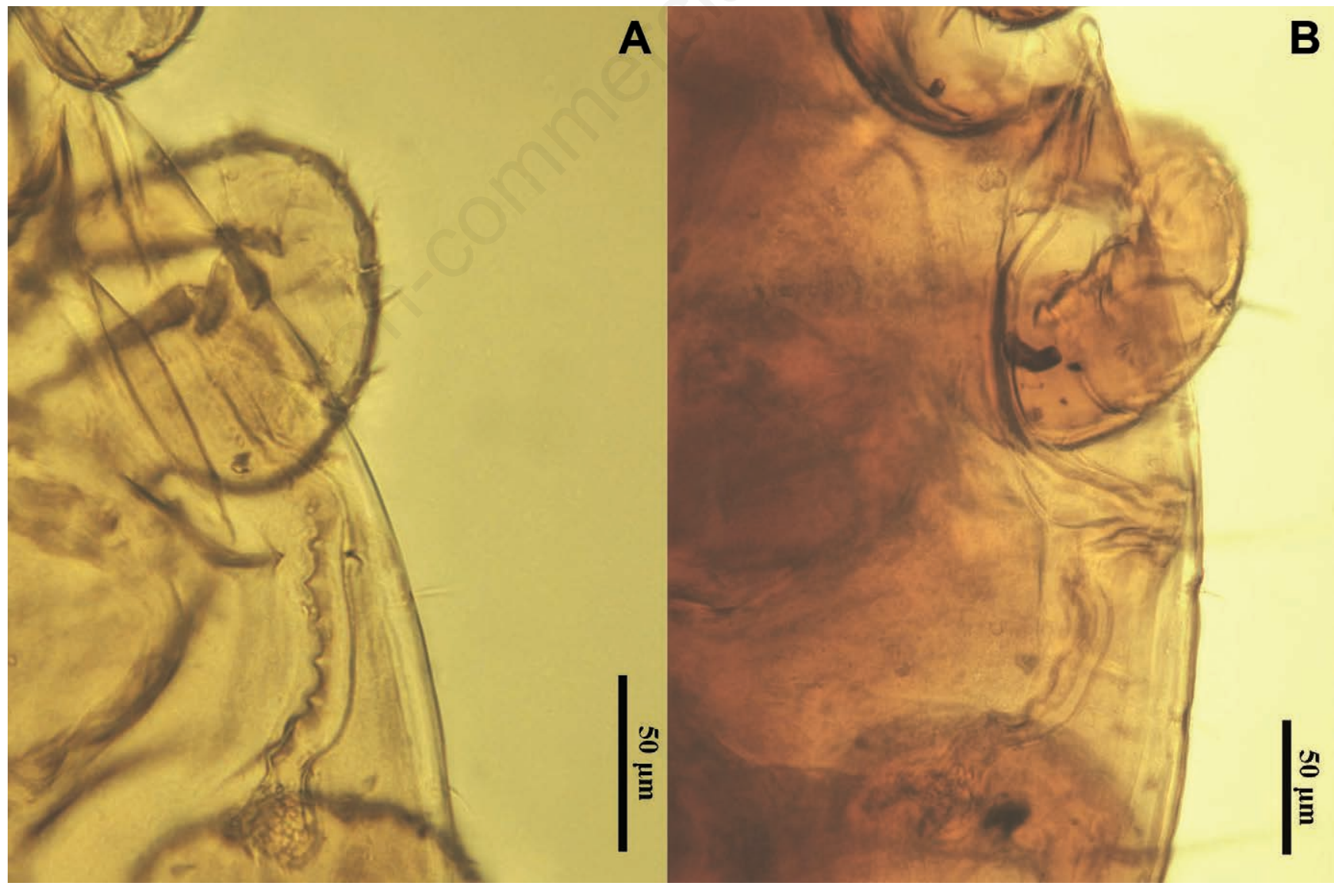

Figure 4. Peritremes and marginal areas of Centrouropoda almerodai (A) and Uroobovella marginata (B). 
This recent case most probably influences beetle biological activities, especially beetles' flight, since Al-Deeb et al. (2011) believe that excessively large number of phoretic mites on $R$. ferrugineus may limit the insect's flight ability. Mazza et al. (2011) also found phoretic deutonymphs of this mite species associated with $R$. ferrugineus in all the sampled sites in Italy, with a great prevalence rate, and showed that the lifespan of mite-infested weevils was decreased in comparison with not infested specimens and caused a cost on beetle activities.

Hitherto, four identified species of the genus Uroobovella Berlese, 1903 have been reported in association with the red palm weevil, mostly in Asian countries, namely $U$. assamomarginata Hiramatsu \& Hirschmann, 1979, U. javae Wiśniewski, 1981, U. krantzi Zaher \& Afifi, and $U$. marginata (Dilipkumar et al., 2015). In this paper, the first record of $U$. marginata in association with $R$. ferrugineus in Iran is introduced. On $R$. ferrugineus, this mite has been previously found in Egypt, Italy, Malta, Turkey and UAE (Dilipkumar et al., 2015). We found that this mite species was adhered to the legs and snout in nearly middle abundance ( 28 and 74 , respectively). Other authors detected $U$. marginata also on some other parts of the weevil's body: on the snout, prothorax, inter-segmental cuticle and ventral abdomen (Mesbah et al., 2008), beneath the elytra (Atakan et al., 2009), mainly on the sternum, pygidium, thorax and head, and rarely on legs and tarsi (Porcelli et al., 2009), and on the head, thorax, terminal part of the abdomen and legs (Ragusa et al., 2009).

Moreover, unknown species of hyperphoretic fungi were observed on the leg segments, especially around coxae and leg grooves II and III, and the setae located at the posterior margin of idiosoma in some specimens of both mite species (Figures 10A and B). The fungal conidia were oval or rod-like in shape with one to four cells. The role of mites in fungal dispersal and potential plant-pathogenicity of these fungi are still unclear. Hassan et al. (2011) found individuals of $U$. marginata in association with undetermined fungi in the case of dead pupae of the red palm weevils. Porcelli et al. (2009) found conidia of the fungus Curvularia sp. on some parts of the bodies in both here discussed species.

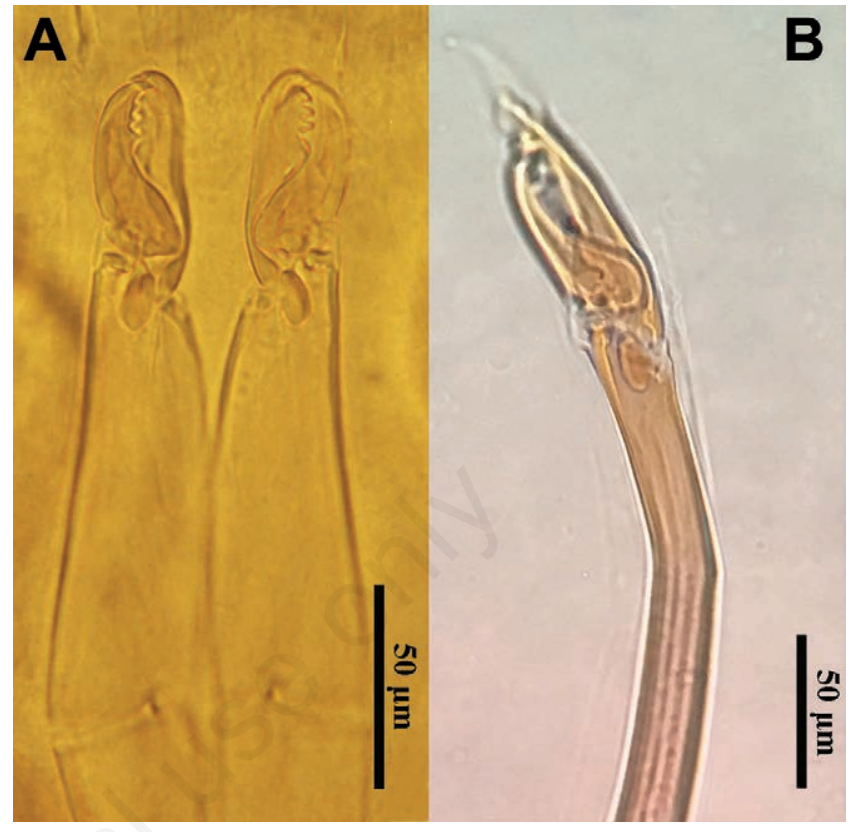

Figure 5. Chelicerae of Centrouropoda almerodai (A) and Uroobovella marginata (B).

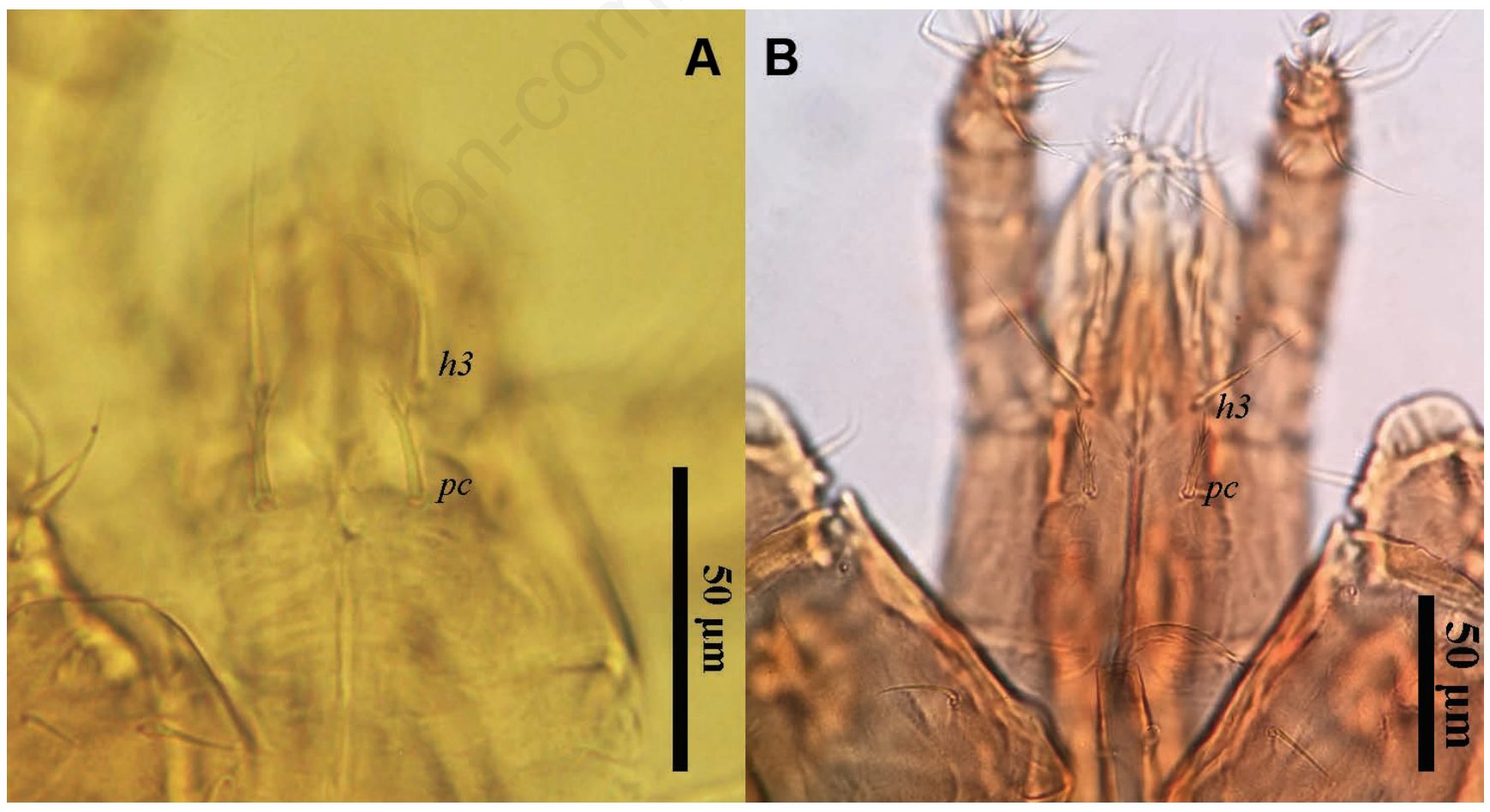

Figure 6. Subcapitulum and hypostomal setae $h 3$ and palpcoxal setae pc in Centrouropoda almerodai (A) and Uroobovella marginata (B). 


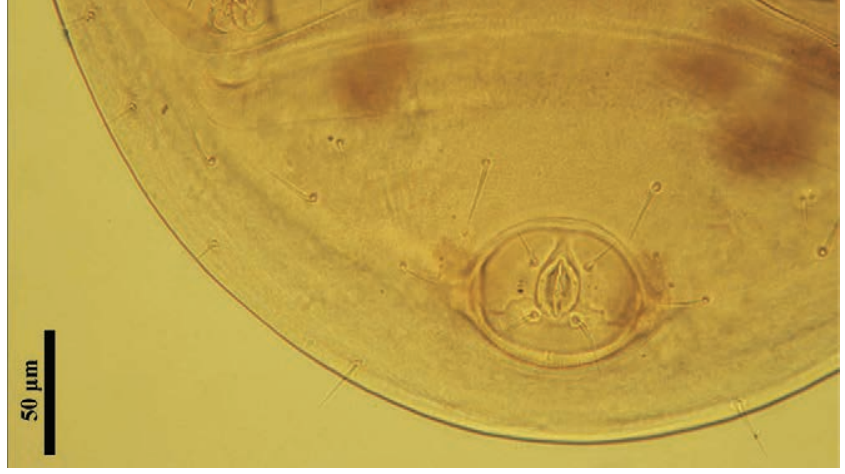

Figure 7. Ventrianal region of Centrouropoda almerodai.

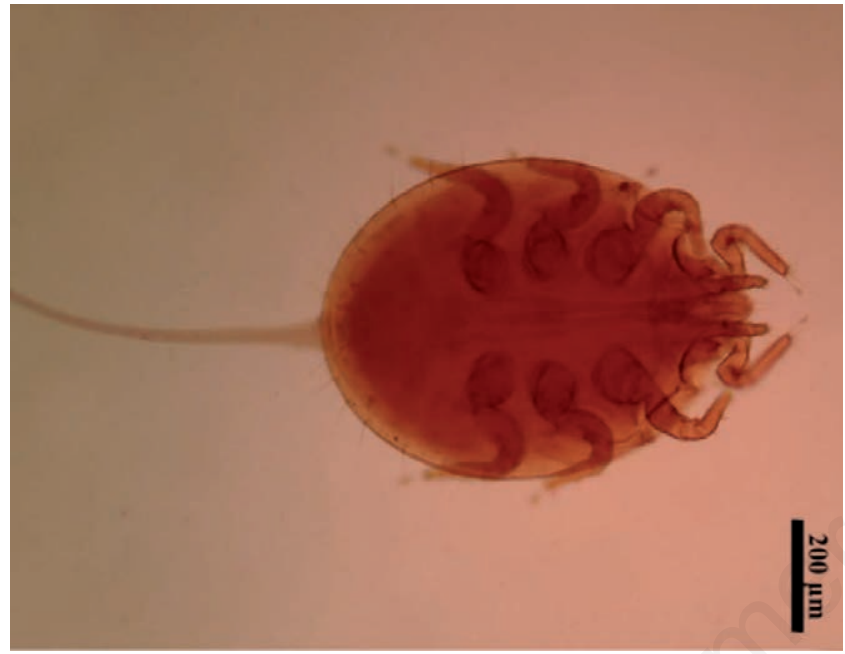

Figure 9. Long anal pedicel in deutonymph of Uroobovella marginata.

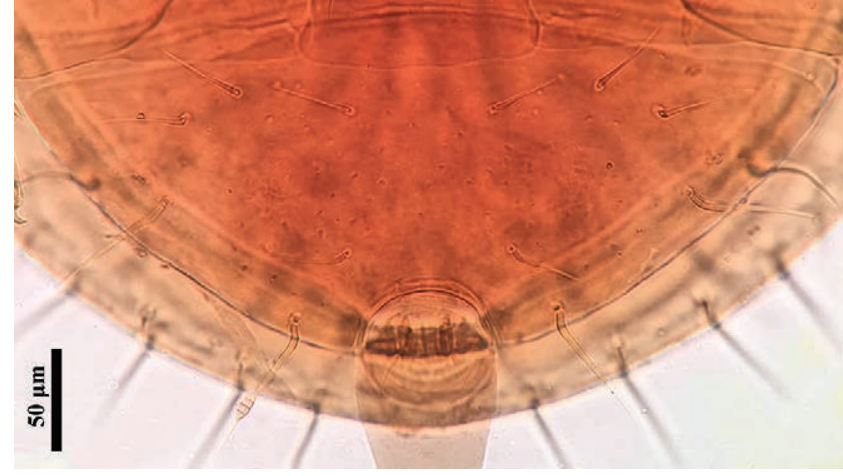

Figure 8. Ventrianal region of Uroobovella marginata.

\section{References}

AL-DEEB M.A., MUZAFFAR S.B., ABUAGLA A.M., SHARIF E.M., 2011 Distribution and abundance of phoretic mites (Astigmata, Mesostigmata) on Rhynchophorus ferrugineus (Coleoptera: Curculionidae). - Fla. Entomol. 94 (4): 748-755.

ATAKAN E., ÇOBANOĞLU S., YÜKSEL 0., BAL D.A., 2009 - Phoretic uropodid mites (Acarina: Uropodidae) on the red palm weevil [Rhynchophorus ferrugineus (Olivier, 1790) (Coleoptera: Curculionidae)]. - Türk. Entomol. Derg. 33 (2): 93-105. (In Turkish).

AVAND-FAGHIH A., 2007 - RPW in Iran. - Available from: http://www.redpalmweevil.com/rpwreport/Iran.htm.

DILIPKUMAR M., AHADIYAT A., MAŠÁN P., CHUAH T.S., 2015 - Mites (Acari) associated with Rhynchophorus ferrugineus (Coleoptera: Curculionidae) in Malaysia, with a revised list of the mites found on this weevil. - J. Asia. Pac. Entomol. 18: 169-174.

FALEIRO J.R., 2006 - A review of the issues and management of the red palm weevil Rhynchophorus ferrugineus (Coleoptera: Rhynchophoridae) in coconut and date palm during the last one hundred years. - Int. J. Trop. Insect Sci. 26 (3): 135-154.
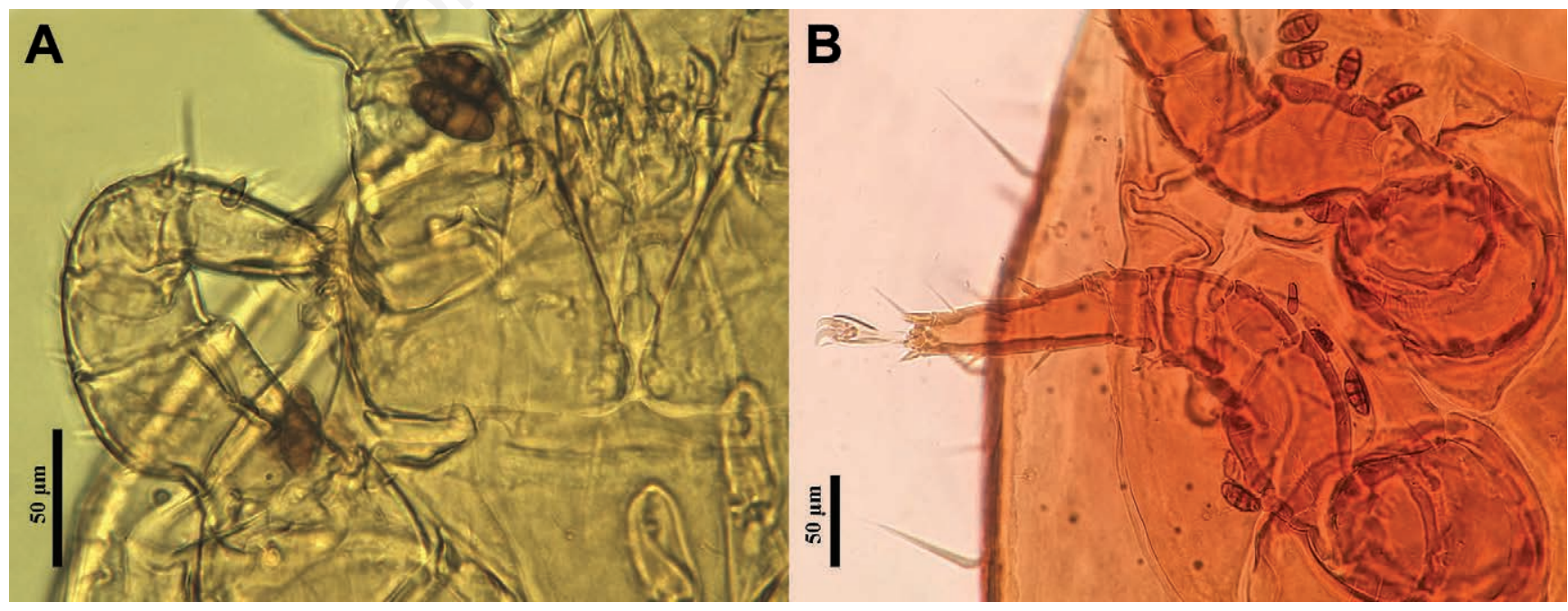

Figure 10. Unknown hyperphoretic fungi attached to the leg segments of Centrouropoda almerodai (A) and the leg segments and fovae pedales of Uroobovella marginata (B). 
HASSAN M.F., NASR A.K., ALLAM S.F., TAHA H.A., MAHMOUD R.A., 2011 Biodiversity and seasonal fluctuation of mite families associated with the red palm weevil, Rhynchophorus ferrugineus Oliver (Coleoptera: Curculionidae) in Egypt. - Egypt. J. Biol. Pest Co. 21 (2): 317-323.

HIRSCHMANN W., ZIRNGIEBL-NICOL I., 1962 - Gangsystematik der Parasitiformes. Teil 6. Uropodiden. Die Gattung Uroobovella Berlese 1903 nov. comb. Teilgänge von Nenteria Oudemans, 1915 nov. comb. Erstversuch der Aufstellung eines Gangsystems der Uropodiden aufgrund der Gnathosoma-Unterseite und Chelicere. Acarologie, Schriftenreihe für vergleichende Milbenkunde, Folge 5, Hirschmann-Verlag, pp. 58-80.

KARG W., 1989 - Acari (Acarina), Milben. Unterordnung Parasitiformes (Anactinochaeta), Uropodina KRAMER, Schildkrötenmilben. - Die Tierwelt Deutschlands, 67. Teil, VEB Gustav Fischer Verlag Jena, $203 \mathrm{pp}$.

KOCH C.L., 1839 - Deutschlands Crustaceen, Myriapoden und Arachniden. Heft 27. - F. Pustet, Regensburg.

KONTSCHÁN J., MAZZA G., NANNELLI R., ROVERSI P.F., 2014 - The true identity of the red palm weevil associated Uropodina mite, Centrouropoda almerodai Hiramatsu \& Hirschmann, 1992. - Redia 97: 83-88.

LONG0 S., RAGUSA S., 2006 - Presence and diffusion of the mite Centrouropoda almerodai Wisniewski \& Hirschmann (Uroactiniinae Uropodina). - Boll. Zool. Agr. Bachic. Ser. II. 38 (3): 265-269. (In Italian).

MAŠÁN P., 2001 - Mites of the cohort Uropodina (Acarina, Mesostigmata) in Slovakia. Annot. Zool. Bot. 223: 1-320. (In Slovak).

MAZZA G., CINI A., CERVO R., LONGO S., 2011 - Just phoresy? Reduced lifespan in red palm weevils Rhynchophorus ferrugineus (Coleoptera: Curculionidae) infested by the mite Centrouropoda almerodai (Uroactiniinae: Uropodina). - Ital. J. Zool. 78 (1): 101-105. MAZZA G., FRANCARDI V., SIMONI S., BENVENUTI C., CERVO R.,
FALEIRO J.R., LLÁCER E., LONGO S., NANNELLI R., TARASCO E., ROVERSI P.F., 2014 - An overview on the natural enemies of Rhynchophorus palm weevils, with focus on $R$. ferrugineus. - Biol. Control 77: 83-92.

MESBAH H.A., DARWISH E.T.E., SALEM S.E., ZAYED T.M., 2008 Associations of three gamasid mite species with the red palm weevil, Rhynchophorus ferrugineus (Oliv.) in infested date palm farms in Beheira, Egypt. - Minufiya J. Agric. Res. 33 (6): 1543-1551.

MURPHY S.T., BRISCOE B.R., 1999 - The red palm weevil as an alien invasive: biology and the prospects for biological control as a component of IPM. - Biocontrol News Inf. 20 (1): 35-46.

PORCELLI F., RAGUSA E., D’ONGHIA A.M., MIZZI S., MIFSUD D., 2009 - Occurrence of Centrouropoda almerodai and Uroobovella marginata (Acari: Uropodina) phoretic on the Red Palm Weevil in Malta. - Bull. Entomol. Soc. Malta 2: 61-66.

RAGUSA E., DI PALMA A., PORCELLI F., 2009 - The association between the red palm weevil Rhynchophorus ferrugineus (Olivier) and its phoretic mites: Centrouropoda almerodai Hiramatsu \& Hirschmann and Uroobovella (Fuscuropoda) marginata (Koch). Abstract IOBC WPRS Work Group "Integrated Control of PlantFeeding Mites", Second Meeting, Florence, 9-12 March, p. 20.

SCHWEIZER J., 1961 - Die Landmilben der Schweiz (Mittelland, Jura und Alpen). Parasitiformes Reuter. - Denkschriften der Schweizerischen Naturforschenden Gesellschaft 84: 1-207.

WALTER D.E., KRANTZ G.W., 2009 - Chapter Seven: Collecting, Rearing, and Preparing Specimens. In: KRANTZ G.W., WALTER D.E. eds. A Manual of Acarology. $3^{\text {rd }}$ Edition. - Texas Tech University Press, Lubbock, Texas, pp. 83-96.

WIŚNIEWSKI J., HIRSCHMANN W., HIRAMATSU N., 1992 - Neue Centrouropoda-Arten (Uroactiniinae, Uropodina) aus den Philippinen, aus Brasilien und Mittelafrika. - Acarologia 33 (4): 313-320. 